\title{
Nigeria, Capitalism and the Question of Equity
}

\author{
Jimoh Amzat* and Olanrewaju A. Olutayo** \\ *Department of Sociology, Usmanu Danfodiyo University, Sokoto, Nigeria \\ **Department of Sociology, University of Ibadan, Ibadan, Nigeria
}

KEYWORDS Social Equity. Capitalism. Child Labour. Slums. Poverty

\begin{abstract}
The emergence of social problems in the modern capitalist system: child labour, tyrannical foremen, teeming slums, poverty, increasing crime and so on are reflections of impaired distributive system. This is because the quest for social equity is contradictory to the development of capitalism itself. This paper examines the incorporation of Nigeria into the world capitalist system and how this entrenched socio-economic and political inequity in the country. The balkanization of Africa, which gave birth to Nigeria, into colonial possessions, broke up previous political and cultural ties with the new political frontiers cutting across old ethnic boundaries. The Nigerian state, like its African counterparts, was confronted with abortive gradual transformation of sociopolitical system which was self-sufficient, which did not need any invisible hand, and which was based on welfarism. The paper submits that the idea behind Structural Adjustment Program (SAP) was a form of dictation of the global capitalism, on new terms, by international financial institutions, to Africa. SAP was a typical journey into the mainstream capitalism and glaring effort that destroyed the failing economy. The paper further examines the evils of SAP and the state of socio-economic equity in Nigeria making it clear that there is embedded inequity in Nigerian 'grafted' capitalist system.
\end{abstract}

\section{INTRODUCTION}

The growth of industrial capitalism (dating back to the $19^{\text {th }}$ century) was a process of interrelated developments, which culminated in the transformations of the western world from a largely agricultural to an over-whelming industrial system. Transformations had always been entrenched in the general developmental process though the transition from feudalism to capitalism is probably of more fundamental importance because this was predicated on production forces and relations. As the society grew with new forces of production, the relations of production became more complex. Embedded in the relations of production is the quest for social justice in the allocation of resources for the general well-being of the society.

The quest for social equity is contradictory to the development of capitalism itself. For instance, the growth of industrial capitalism required the efficient use of cheap raw materials, such as iron, coal, agricultural products, labour and so on. This implied that industrial growth had some series of other supportive requirements most of which were beyond Europe. Growth in

Address for correspondence:

Amzat Jimoh

Department of Sociology,

Usmanu Danfodiyo University, Sokoto, Nigeria

Telephone: +2348034339221.

E-mail: greatjoa@yahoo.co.uk one industrial sector required growth in another. For instance mass production, in turn, increased the demand for growth canals and later railways (Chambers et al. 1999). Mainly, the development of industrial capitalism is based on two kinds of exploitation: Exploitation of the environment and natural resources and social and economic exploitation (of others). A distinct phase in the development of capitalism was the stage of primitive accumulation of capital. This free capital came from two sources: the first was colonial plunder; the sacking of the wealth of the peripheral areas of the world. The second source was the old feudal system itself which necessitated the dispossession of the land of the peasantry thereby rendering them propertyless (Roxborough 1979).

This primitives accumulation of capital explains the different emergence of social problems in the modern capitalist system: child labour, tyrannical foremen, teeming slums, and social policies as the growing prosperity and security of the middle class contrasted sharply with the distributions of the urban poor (Chambers et al. 1999). Industrial capitalism attained and survived in the midst of socioeconomic and political inequity (put earnestly social problems) in Europe. This accounted for numbers of strikes and violent outbursts from the factory workers (Smelser 1968). The living conditions in England were so poor that Chambers et al observed: 
What was new was the terrible crowding in industrial areas and the workers' helpless dependences on their employers. The conditions in which workers lived made poverty more miserable, more obvious to all, and more threatening to the general welfare.... Squeezing whole family into a single room and cramming individuals and thousands of people in salubrious waters, and with no means for disposing of sewage... in Europe, members of the working class were recognizably thinner, shorter, and paler than the people.. brought demoralizing dependence... unemployment was the norm... and paupers was acknowledged to be the social disease of the century..."

Then new words emerged: social classes, urban slum, poverty, unemployment, child labour, prostitution, and so on. The growing wealth of financial speculators brought about by exploitations (of the environment) and exploitation (of others) made the search for cheap labour and profit inevitable. Expansion (imperialism) thus stemmed from the manipulations of public opinion in the interest of certain capitalists, thereby transforming it into states' policy (Chambers et al. 1999). This explains the capitalist expansion and the subsequent incorporation of the periphery into the capitalist economy. The question then is how enviable are the social conditions precipitated by industrial capitalism that could justify replicating (the tradition) in the 3rd world?

There is the tendency to point that global relation provides the avenue for the negation of the internal social discrepancies in the 'core' and subsequent transfer of such to the periphery thereby paving the way for the alleviation or mitigation or almost elimination of vectors of underdevelopment in the 'core'. Magdoff (1987) observed:

At first, the new colonial powers of Western Europe used their military prowess to pursue the well-trodden paths of plunder, piracy and annexation of foreign territory. But at the time Europe was in the thresholds of major upheavals: the seeds of the capitalist mode of production were sprouting. The commercial revolution of the sixteenth and seventeenth centuries, which unfolded along with the geographical discoveries and overseas conquests, helped break down the feudal barriers to production and accelerated the rise of capitalism. [This culminated in relative socio-political and economic stability in Europe then and thereafter as they exploit and exploit].

The mainstay of capitalism as a dominant mode of production around the globe has called for enormous social upheaval as regards the question of distributive justice especially in the 'global' relation of production. The global relations of production consist of both the developed and the third world or what Wallerstein (1980) called the core and the periphery (respectively). The periphery was impatiently incorporated into the world capitalist system through different system of exploitative relations.

The Cold War, and its eventual demise, led to a gradual depolarization of the world in terms of world system of production. Nonetheless, the emergence of new poles, in Africa, has not been mutually beneficial. The so called branches have strived in different forms of socioeconomic and political fracas which have made life meaningless in such region. Nigeria is not left out of these seemingly problems. Karl Marx must have been right again to argue that all other infrastructures depend on the economic superstructure! The question is whether the Nigerian grafted capitalism mimics the general situations of economic instability, corruption, poverty, ethnic strife and socio-economic inequity that manifested in nineteenth century Europe? The general concern of this paper is to examine the systematic absorption of Nigeria into the world capitalist system and certain strategies of exploitative relations that account for such absorption. The paper will also account for how the 'grafted' capitalism has thrived, with the social problems in Nigeria.

\section{THE INCORPORATION OF NIGERIA INTO THE WORLD CAPITALIST SYSTEM}

Before the advent of colonial rule, what became Nigerian societies lived in clans and empires. In the West, there existed different empires and communities, in the north, there was the caliphate, and in the East, were diversed communities. Before the advent of colonialism, hunting and gathering, fishing, animal husbandry, agriculture and its various combinations were the major types of food acquisition in the African continent (Asamoa 2001). The economy 
was totally traditional and self-sufficient. The economic system was based on trade by batter and gave little or no room for capital accumulation. The system was redis-tributive and based on communal ownership system. There was really what Durkheim called mechanical solidarity. For Durkheim the central fact of the transition from traditional to modern society was dissolution of old ties (depended on spatial contiguity and personal acquaintance) of mechanical solidarity, which existed during the pre-industrial as pre-colonial era (Roxborough 1979). There was no or very limited degree of class and state formation. There were respected social nobilities such as the kings, chiefs, elders, warriors and priests. Nonetheless, this was not a static society as contestations, through wars, were prevalent.

Colonialism became a major revolutionary agent transforming the whole socio-political economy of Africa. The balkanization of Africa, which gave birth to Nigeria, into colonial possessions, broke up previous political and cultural ties with the new political frontiers cutting across old ethnic boundaries (Asamoa 2001; van der Walt 2003). van der Walt (2003: 13) in this note, asserted:

The traditional Africans' political identity did not define their ethnic identity and vice versa. The colonial practice of linking political identity to ethnic identity introduced something new and foreign into African society, viz the politicization of ethnicity, based on European model of nation-states.

This imposition of new system of production and rule was the greatest impediment in the development of Africa/ Nigeria. The natural process of social evolution was interrupted. It is in the same vein that Kasfir (1988) claimed that:

The colonial African State was given responsibility for a more extensive and ramified task than any state in Europe had dreamt of undertaking at home: The integration of entirely new forms of local production into metropolitan capitalism... Economic dislocations of this magnitude necessarily reshaped the distribution of local opportunities to create wealth, and thus also revolutionalised class stratification.

The burden of the social dislocation was too enormous to bear. The Nigerian state, like its African counterparts, was confronted with abortive gradual transformation of socio-political system which was self-sufficient, which did not need any invisible hand, and which was based on welfarism.

Part of the social dislocation was the monetization of the economy. The system of production that was not capitalistic was monetized through the destruction and replacement of the existing monetary system. This led to the commodification and objectification of all aspects of economic and social relations. In Nigeria, the new currency system was sustained through the introduction of forced labour and taxation. This gave rise to the proliferation of wage labour which facilitated imperialist grip of the economy (Chizea 1984). The new form of relations was typical stride towards gradual abortion of Nigeria into the mainstream of capitalist economy. Chizea (1984) further observed that the monopolistic character of the colonial economy reflected the monopoly base on metropolitan capital to which it was linked in a dependent relation. This form of capitalist mode of production in Nigeria (and Africa in general) by-passed the normal historical development and advanced into monopoly stage.

Several other researchers have argued in the same direction that colonialism was the major factor responsible for 'grafted' capitalistic economy in Nigeria. This was the major outcome of the ten decades of British rule in Nigeria (Adebo 1984). It was masterminded through the subjugation of the indigenous population to the needs and objectives of imperialism (Baran 1957; Rodney 1974; Amin 1976). The 'induced' abortion' of the normal and sequential development process of social formation in Nigeria allowed for the entrenchment of inequality and inequity and the structures that preserve them. To Aminu (1974), capitalism has become a world system and thus the social contradiction characteristics of capitalism are thus on the world scale that is between world bourgeoisie and the world proletariat. This arrangement has percolated into the different 'dependent' capitalist structures

The subjugation of the Nigeria indigenous economy left a kind of 'neurological abnormality' in the Nigerian state. Nothing was fundamentally revolutionized, except the grafting of new 'foreign' elite on the indigenous ones (Olutayo et al. forthcoming). This, we may assert, is responsible for the 'stunted' development process over the years.

The transfer of resources from periphery to the centre and such circulation may give rise to 
various blocking mechanisms, which hold back or distort the economy of the periphery thereby preventing an allocation of resources, which will produce economic growth (Roxborough 1979). This significantly could explain the primitive accumulation of capital and stratification system in Nigeria. The British created the petty bourgeoisie which was made up of Chiefs, businessmen, professionals, military and police officers prior to independence in 1960 (Chizea 1984). The varying classes, more than four decades after independence, are still dominant today.

- The Imperialist Bourgeoisie or sometimes called "Imported oligarchy" (Onimode 1983). This consists of the foreign personnel that are still accorded with 'Sirs'. They own and control the multinational corporations in Nigeria. They have great access to the government and enjoy undue privileges. This may, perhaps, explain resource conflict in the Niger Delta of Nigeria.

- Indigenous Bourgeoisie: this group mainly consists of former rulers who have drained the treasury of the country. They also include the 'pseudo' contractors who merely serve as means of looting the treasury; businessmen who hold the 'big' licenses of importation and other parasitic speculators, the 'hold-in-trusts' etc. These have become 'important' politicians thus legitimizing their access to the treasuries of the country.

- Bureaucratic Bourgeoisie: the top bureaucratic officers, professional groups, top government officials, military and others who are involved in designing and implementing the programs of the state.

- Traditional rulers: emirs, obas, obis, obongs who collude with the government in exploiting the masses (Chikendu 1984).

- The proletariats: consist of the millions of teeming labourers, peasant farmers, jobless graduates, underemployed workers, criminals, beggars, prostitutes, the poor and the aged. Most of these constituted what Spitzer (1971) called the "problem population".

The proletariats are the "problem population" because they have little or no input in the capitalist production system. They are to obey and not to propound the laws; to be employed (if any), to be loyal, to vote and to continue struggling for (ceaseless) better tomorrow.

Chikendu (1984) further examined the production of exploitation in the Nigerian State. The first crop of wealthy Nigerians made their fortunes from the sweat of the peasant farmers though the so called Marketing Boards. Nigerian agents bought cash crops at low price from the peasant farmers and sold to the board at high price. The product were then exported for processing and finished goods, and brought back to Nigeria, by these agents/allies, at exorbitant prices.

In another dimension, violence was the major weapon utilized in the incorporation of Africa and Nigeria in particular into the mainstream of global capitalist economy. The three levels of violence were psychological, structural and physical violence (Fanon, 1963), a combination of which put Nigeria and other third World countries in dreadful and pitiable condition; a combination of which drained both material and non-material resources of Nigeria. This is why the country is bedevilled with corruption, ethnic strife, indebtedness, structural degradation, institutional decay, poverty, unemployment, brain-drain, America-visa lottery seeking, bad governance, drug trafficking and state breakdown. The system of socio-economic and political robbery entrenched by the colonialists is still in domestic form (especially in form of corruption) after independence. It is in line with the foregoing that Olutayo (2002) asserted that "dependent capitalism" is the dominant means of survival virtually in all African countries. Dependency is a situation which a certain group of countries have their economies conditioned by the development and expansion of another economy to which there own is subjected (Roxborough 1970)

Furthermore, at independence, the structural decay in Nigeria, and Africa in general, was glaring, but state interventions was expected to overcome them. The unbroken alliance with the capitalist dictations further retards the efforts of the state. The political bourgeoisie who took over the government compliantly continued to serve the goals of their colonial predecessors. Nigeria still continued to serve the role of primary product exporter and profoundly failed in exploiting 'pseudo' industrialization (import - substitution) in the country.

A 'failed' state was handled over to the indigenous bourgeoisie, and the state, in its failure, also failed through a demonstration of colonial 'mentality', incompetence, inexperience and sycophancy. The imperial loyalty among the indigenous bourgeoisie set Nigeria backward and too backward to be saved form falling into 
the trench of underdevelopment from which it battles after the 'flag' independence, till today. The capitalist stratification is widening and survives in the midst of oligarchic recycling of power among the then indigenous bourgeoisie and their generations till date. What has been discussed so far may quite be the giant stride into capitalist venture, the journey still continues. The next session will consider another giant side towards capitalism.

\section{THE NIGERIA STRUCTURAL ADJUSTMENT PROGRAM ('SAP') EXPERIENCE}

The third world situation worsened in the 1970s. Saul and Leys, (2005), observed that by the 70s, the terms of trade had turned against African agricultural products. While oil prices also hit most of them hard, debt became a crippling burden as the era of high interest rates set in, and Africa's own economic backwardness discouraged any great influence of private capital from abroad. Then, the age of Structural Adjustment Program (SAP) set in. The idea behind SAP was a form of dictation of the global capitalism, on new terms, by international financial institutions, to Africa. In Nigeria, the oil boom accounted for the shift from agricultural production to other non-oil exports to petroleum, construction and service industries. This accounted for Nigeria's dependence on a single commodity, as the main source of foreign earning. It led to shortage in agricultural production and subsequent importation of basic food to meet the requirements of the population (Osakwe 1993). It also led to the decline in the production of cash crops which starved the local industries (that needed such products) out of the market. Hence, unemployment rose and poverty became a central feature of the Nigerian population. According to the then government, all these prompted International Monetary Fund (IMF) supported Structural Adjustment Program.

SAP was a typical journey into the mainstream capitalism and glaring effort to destroy the failing economy. Onimode (1992) observed:

[Nigeria's] crisis and the IMF and World Bank Stabilization and Structural Adjustment Programmes have generated and exacerbated a serious decline in the African economy, and created the catastrophes of suffering facing the rural and urban poor, women, children, workers, peasants and other vulnerable social groups.

The acceptance and implementation of SAP suggest again that the African leaders are neocolonial vassalage representing the interest, and under the control of the UN and other donors. Some of the deteriorating measures of SAP include the:

- Adoption of 'realistic' exchange rate policy which necessitated the 'correction' of over valuation of Naira.

- Attraction of net inflow of foreign capital which accounted for the proliferation and infiltration of economic holdings.

- Rationalization and privatization of public sector which promote oligarchic private ownership and, at the receiving end, the teeming millions of masses who are mostly unemployed.

- Removal of oil subsidy which further incapacitated the then economically handicapped citizens. This also cleared the way for price 'galloping'.

- Austerity measures as regards minimization of the public expenditure (especially welfare function of the state). This accounted for deficit budgets, decay in infrastructures and hardship among the populace.

- Constraints on the growth of public wage bill even when inflation galloped (drastically). This pauperized the wage - earners which also led to decline in economic activities of non-wage earners.

According to a critic of SAP, removing the entire subsidy without increasing nominal wages demonstrated the inhuman face of Nigerian SAP (Essien 1993). SAP is simply a capitalist and neo-colonialist adventure which led to the collapse of the foundation and structures of socio-political welfarism; leading to full-blown capitalist entity and economic hardship. By the end of the twentieth century, it became glaring that SAP has worsened the socio-economic and political situation in Nigeria, like its most African counterparts. The current wave of general efforts towards development is the Millennium Development Goals (MDGs) which were set in 2000. By 2007, it was clear that poverty was still endemic and that most nations would not meet the target set in the MDGs. Though significant steps were taken to correct the situation, freemarket and 'good governance' are still the means 
Table 1: Some development indicators

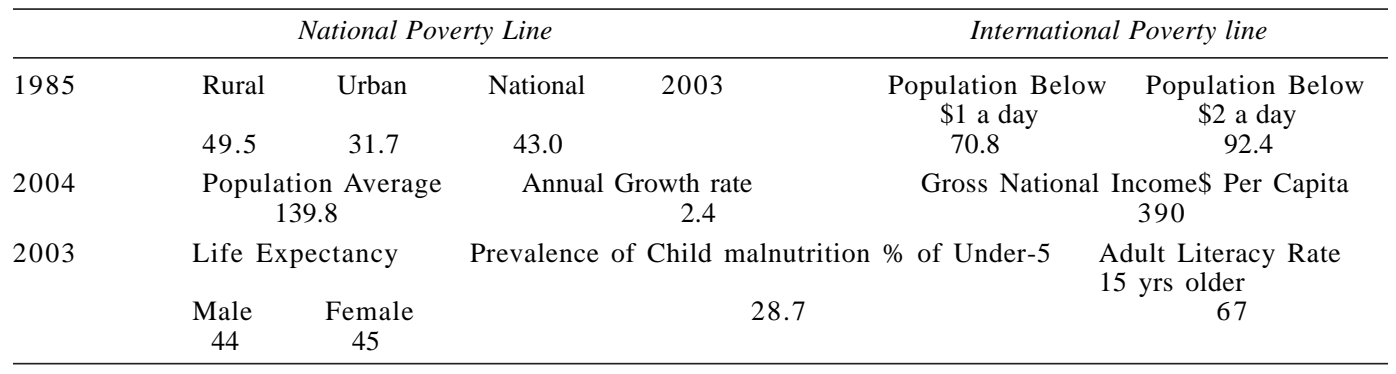

Source: IBRD and World Bank, 2006 World Development Report.

by which poverty, through a reduction in inequality and inequity, is expected to be reduced.

\section{STATE OF SOCIO-POLITICAL AND ECONOMIC EQUITY IN NIGERIA}

There is no definite consensus on sociocultural inequity or equity as it means different things to different people, especially in different professions. While lawyers may think of access to Justice and fundamental human rights, economists may think of social 'optimum' and sociologists may talk of equality in terms of wealth, prestige and power in the society. IBRD/ World Bank (2005) defines equity in terms of two basic principles.

- Equal opportunity: This implies that predetermined circumstances - gender, race, place of birth, religions, family of origin, or any other form of social group should not determine whether people succeed econo- mically, socially and politically. It is further argued that the outcome of a person's life should reflect mostly his/her efforts and talent. It can be observed, however, that talents are not evenly distributed and efforts are not equally enhanced within the social context.

- Avoidance of absolute deprivation: This is another criterion used to define equity. This takes care of the absolute while neglecting the 'relative' which is even more paramount. Equity and inequity are usually experienced in relative terms. This makes the definitional principle of equity deficient.

In a typical third world country like Nigeria, following the criteria and their embedded deficiencies, the widening inequity in the society is socially detrimental to the well being of Nigerians.

Central to income inequality is the relevance of certificates which are usually attained through

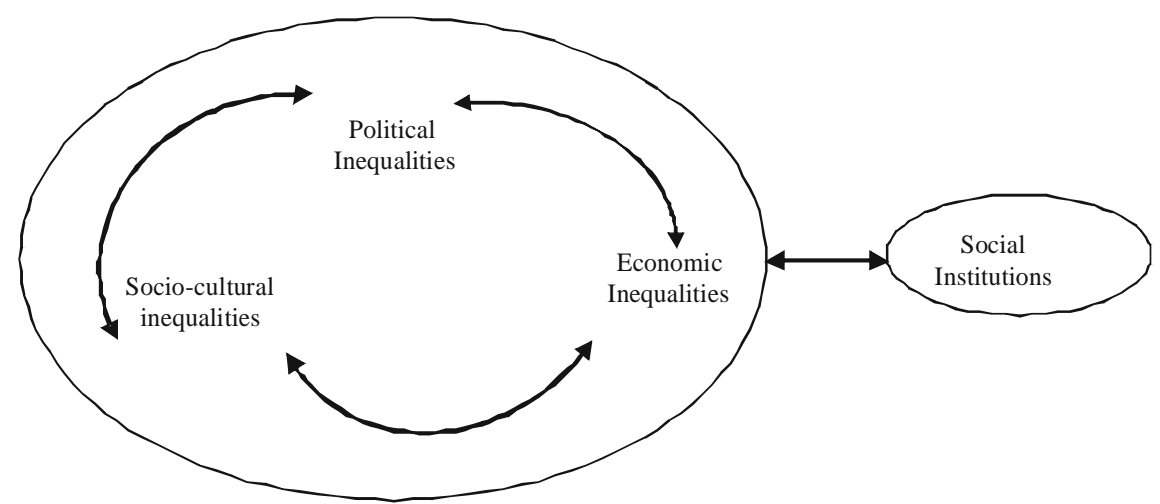

Fig. 1. Three spheres-Socio-cultural, political and economic inequalities interact to produce and reproduce inequity in any capitalist society and shape the institution rules in all societies. Source: IBRD/World Bank, 2005 
training and education. In a place, where educational opportunities are not evenly distributed within the society, equal opportunity is not sustained (see table 1 for some development indicators in Nigeria). This is further complicated where equal employment opportunities are not available to the people. Thus, transition from school to work, healthy life and, indeed, family formation and citizenship may be hindered. These are the concerns of an on-going research to be published in 2006 as World Development Report 2007 (http: // web.worldbank.org/WBSITE/EXTERNAL/ EXTDec/EXTRESEARCH/EXTWDR2007/ 0,,contentMDK: 20601690 menuPK: 1489853 pagePK: 64167689 p: PK.641676 1 accessed $6^{\text {th }}$ February 2006)

Figure 1 suggests that the three spheres (socio-cultural, political and economic inequalities) interact to produce and reproduce inequity in any capitalist society, and shape institution and rules in all societies (IBRD/World Bank 2005). Unequal economic power leads to unequal outcomes and inequity is inimical to long-term prosperity and a system that sustains it should be redressed. Capitalism preserves, produces and reproduces inequalities and inequities in all spheres of life.

It is glaring that the inception of capitalist history accounts for the reification of the government and its consequent over-valuation as an instrument to self-gratification. This accounts for incessant political instability. Even in the democratic administration, the feasibility of coup, and history of abortive coups are imminent in some developing countries. Now the state primarily functions to maintain conducive condition for the production and reproduction of unequal exchange-capitalism. This invariably accounts for prebendalism in the socio-political formation and is a reflection of the capitalist motive, especially in Nigeria. As Joseph (1983) opined, prebendalism is a;

Pattern of [socio-] political behaviour which reflects as their justifying principle that the offices of the existing state may be competed for and then utilized for the personal benefit of office-holders as well as that of their references or support group.

There are countless cases of prebendal politics at local, state and federal levels during Obasanjo's democratic administrations. The incessant removal and replacement of senate
Presidents, Ministers, Governors and so on are typical examples 'With the transition to democratic rule, there is "legitimized' prebendalism. This appropriation of illegitimate economic opportunities especially in their socio-political arena started at a point in history and is sustained and justified by the system of production and distribution. Presently, the fact that the President of the Federal Republic of Nigeria can establish 'monuments' through his 'dependents' in business without being cautioned by the legislatives clearly illustrates the point. Even though seen to be the prerogatives of the houses of assembly in Oyo and Anambra states, the roles of 'political godfathers' in politics clearly show the existence of prebendalism but, of more significance, it seems, is the conspiracy at the federal level. This may not be surprising as those who control the socio- economic and political arena do not own the means of production. Access to state power therefore becomes a 'profit-driven' venture. Indeed, this increasing prebandalism is, according to Goudzwaard (1996), is a result of the increasing liberation and deregulation of the world economy leading to the increasing instrumentalization of the state for economic interests. The state, like the other societal relationships, is increasingly commercialized. Until those who can independently control the means of survival manage to gain the control of political arrangements, the patterns of inequalities and inequities prevalent in Nigeria would persist. Only this group would want to sustain production and, hence, institute social welfare policies to, at least, 'alleviate' poverty.

\section{REFERENCES}

Adebo A 1984. The State and Underdevelopment in Nigeria: A Theoretical Perspective Proceedings of the Eleventh Annual Conference of the Nigeria Political Science Association Held at University of Benin May $16-18^{\text {th }}$ (1984).

Amin S 1974. Accumulation on a World Scale. NY: Monthly Review.

Amin S 1976. Accumulation on a World Scale. NY: Monthly Review.

Baran P 1957. The Political Economy of Growth. NY: Monthly Review.

Chambers M, Hanawalt B, Rabb TK, Wolody I, Grew R 1999. The Western Experience. $7^{\text {th }}$ Edition, Boston: McGraw Hill. Boston.

Chikendu PN 1984. The State as a Partial Umpire in the Class Struggle: The Nigerian Example. Proceedings of the Eleventh annual Conference of 
the Nigerian Political Science Association held at University of Benin - May $16-18^{\text {th }}$ (1984).

Chizea B 1984. Towards a Theoretical Understanding of the State in Nigeria. Proceedings of the Eleventh annual Conference of the Nigerian Political Science Association held at University of Benin - May 16 - $18^{\text {th }} 1(984)$.

Essien E 1993. The Structural Adjustment Programme: Implementation, its Gains and Losses. In: JO Osakwe (Ed.): Seven Years of IBB. Vol. 2, Daily Times of Nigeria, Lagos, pp. 44-82.

Fanon F 1963. The Wretched of the Earth. London: Penguin Books.

Goudzwaard B 1996. Globalization, exclusion, enslavement Reformed World, 46(3): 99-108.

Joseph RA 1983. Class, State and Prebendal Politics in Nigeria The Journal of Commonwealth and Comparative Politics, XXI(3): 19-38.

Kasfir N 1983. Delating Class to State. African Journal of Commonwealth and Comparative Politics, XXI (3): $1-20$.

Magdoff H 1982. Imperialism: A Historical Survey. In: H Alavi, I Shanin (Eds.): Introduction to the Sociology of Developing Societies. London: Macmillan Press, pp. 1-5.

Olutayo AO 2002. The Concept of Mode of Production in the Analysis of Development, In: UC
Isiugo-Abanihe, AN Isamah, JO Adesina (Eds.): Currents and Perspectives in Sociology. Ibadan: Malthouse Press Ltd., pp. 138-148

Olutayo AO, Olutayo MA, Omobowale AO. In Press. 'TINA': Aids and the Underdevelopment Problem. Onibode B 1983. Imperialism and Underdevelopment in Nigeria. Nigeria: Macmillan Press Ltd.

Onibode B 1992. A Future for Africa: Beyond the Politics of Adjustment. London: Earthscan.

Osakwe JO 1993. Structural Adjustment Programme (SAP): Aims, Objectives and Rationale. In: JO Osakwe (Ed.): Seven Years of IBB. Vol. 2, Daily Times of Nigeria. PLC, Lagos.

Rodney W 1974. How Europe Underdeveloped Africa. Tanzania: B'ogle L'overture.

Roxborough I 1970. Theories of Underdevelopment. London: Macmillan Press Ltd.

Spitzer S 1971. Towards a Marxian Theory of Deviance. Journal of Social Problems 22(5): 638-656.

Wallerstein I 1980. The Capitalist World Economy. Cambridge: Cambridge University Press..

Wallerstein I 1974. The Modern World System. NY: Academic Press.

Van der Walt BJ 2003. Understanding and Rebuilding Africa: from Desperation Today to Expectation for Tomorrow. Potchefstroom: Institute for Contemporary Christianity in Africa. 